\title{
Corporate Financial Constraints and Internal Capital Markets: Evidence from Emerging Countries
}

\author{
Mine Uğurlu ${ }^{1}$, Ayşe Altık-Yılmaz ${ }^{2} \&$ Elif Akben-Selçuk ${ }^{3}$ \\ ${ }^{1}$ Department of Management, Boğaziçi University, Istanbul, Turkey \\ ${ }^{2}$ Department of Business Administration, Bahçeşehir University, Istanbul, Turkey \\ ${ }^{3}$ Department of Business Administration, Kadir Has University, Istanbul, Turkey \\ Correspondence: Mine Uğurlu, Department of Management, Boğaziçi University, Bebek, Istanbul, 34342, Turkey. \\ Tel: 90-212-359-5400
}

Received: November 30, 2016

Accepted: December 16, 2016 Online Published: December 28, 2016

doi:10.5430/afr.v6n1p25

URL: http://dx.doi.org/10.5430/afr.v6n1p25

\begin{abstract}
This paper investigates whether the internal capital markets of business groups mitigate the financial constraints of affiliated firms,and affect their financing policies.It aims to extend the evidence on internal capital markets to emerging countries where financing constraints are prevalent, and adds to the literature on trade credit by revealing that the distressed group-affiliated firms rely less on trade credit than their non-affiliated counterparts despite the positive relation between trade credit and distress. Group firms that have high investments in prior periods use less trade credit in the subsequent periods than non-affiliated firms. The study rests on panel data regressions covering 3906 firms from six emerging countries for the 2006-2012 period. The findings indicate that the Q-sensitivity of the investments of affiliated firms is lower than that of their unaffiliated counterparts in all countries and that the investment cash flow sensitivity of affiliates is lower in five countries, strongly indicating that group-affiliated firms are financially less constrained. The distressed group firms use significantly lower leverage than distressed unaffiliated firms despite the positive relation between distress and leverage. Group firms in high-Q industries invest less than unaffiliated firms. This paper contributes to the existing literature on internal capital markets by expanding the scope to emerging countries where market imperfections and financing constraints are more pronounced, and provides strong evidence for the role of business groups, prevalent in most emerging countries, in mitigating the constraints on the investments and financing choices of the group-affiliated firms.
\end{abstract}

Keywords: Business groups, Emerging markets, Internal capital markets, Capital investments, Leverage, Trade credit, Financial distress

\section{Introduction}

There is strong evidence on the Q-sensitivity of corporate investments in developed and emerging markets while the evidence on the impact of internal capital markets of group-affiliated firms on their financial flexibility mainly rests on developed markets. This research aims to fill this gap by extending the evidence on the effects of internal capital markets on corporate financial flexibility to the emerging countries where financial constraints are more pronounced.Furthermore, this paper adds to the existing literature on trade credit financing of distressed firms by incorporating the effects of internal capital markets on the financing choices of distressed group-affiliated firms.The results show that the distressed group affiliates rely less on the use of trade credit than the unaffiliated distressed firms.The group-affiliated distressed firms significantly use lower leverage than the unaffiliated distressed firms. So,this research documents that group firms that face distress use less trade credit and leverage which rank lower in financing hierarchy than internal funds.

Frictions in capital markets such as economic downturns, credit crunches, and information asymmetry between lenders and firms result in financial constraints for corporations. The evidence resting on 44 emerging countries reveals that, for firms in poorly developed financial markets, trade credit may provide an alternative source of funds despite the fact that it ranks lower in pecking order hierarchy than debt and internal funds. Evidence shows that industries with higher dependence on trade credit financing exhibit higher rates of growth in emerging countries where relatively weaker financial institutions dominate (Fisman \& Love, 2003). Empirical evidence displays that trade credit can be a substitute for institutional financing where financial intermediaries are scarce (Petersen \& Rajan, 
1997).

The recent slowdown in investment growth in emerging markets has led many researchers to focus on the determinants of corporate investment in these countries. Most have highlighted the importance of internal financing for firms, owing to capital market imperfections, low savings, and lack of solid track of foreign direct investments (FDI) which can lead to lower investment in these countries. In emerging markets, where financial intermediaries and markets are less developed, firms tend to rely on internally generated funds. A recent study involving 38 emerging markets documents that Tobin's Q, cash flow sensitivity of investments, foreign direct investment (FDI) flows and export prices are important drivers of investment outlays in these countries (Magud \& Sosa, 2015). In the presence of financial frictions, access to external financing for profitable investments may be limited, in which case investment decisions would be determined not only by the availability of investment opportunities but also by the availability of internal funds.

The prevalence of business groups in emerging countries makes the internal capital markets of these groups an important alternative for reducing financial constraints. A stream of literature on developed markets indicates that internal capital markets mitigate financing constraints of corporations (Stiglitz \& Weiss, 1981; Myers \& Majluf, 1984; Greenwald et al., 1984). Investment cash flow sensitivity (ICFS) has been widely used as a measure of financial constraint despite criticisms expressed in the finance literature. Most research on capital investment determinants is based extensively on Tobin's Q investment models, and investment cash flow sensitivity (ICFS) which is employed as indicator of financial constraint (Fazzari et al., 2000; Fisman \& Love, 2003; Carpenter \& Guaraglia, 2008; Ozbas \& Scharfstein, 2009; Attig \& Cleary, 2014; Magud \& Sosa, 2015). Numerous studies find that the more financially constrained firms display higher ICFS than less constrained firms (Fazarri et al., 1988; Almeida \& Campello, 2007; Beatty et al., 2010). Some studies have incorporated proxies that affect the relationship between ICFS and investment outlays such as the marginal cost of capital (Cleary et al., 2007), management quality practices (Attig \& Cleary, 2014) and FDI (Magud \& Sosa, 2015) so as to resolve the contradictory views on the use of ICFS as an indicator of financial constraint.Evidence from developed countries reveals that the internal capital markets of conglomerates may enable subsidiaries to fund profitable investments that the external capital market would not be able to finance because of information asymmetries and agency costs that make external financing costly (Williamson, 1975; Gertner et al., 1994; Stein, 1997; Fluck \& Lynch, 1999; Maksimovic \& Phillips, 2013).

As Khanna and Yafeh (2005) indicate, business groups are prevalent organization structures that exist in different forms in emerging markets. Business groups can have pyramidal structures, which may have significant effects on capital allocation, financial development and $\mathrm{R} \& \mathrm{D}$ investments in emerging markets (Morck et al., 2005). Internal capital markets are expected to mitigate the financing constraints of the affiliated firms in emerging countries, where financial institutions and markets are less developed. It is expected that group-affiliated firms in emerging markets will have lower sensitivity of investment to its own cash flows than unaffiliated firms.

The first part of this study investigates the relationship between investment cash flow sensitivity (ICFS) and capital expenditures in six emerging countries during the 2006-2012 period, employing business group affiliation as an important factor that might affect this relationship in addition to the use of fundamental drivers of investment such as investment opportunities (Tobin's Q), and exports. While there are several studies that have focused on the effects of conglomeration on capital allocation (Shin \& Stulz, 1998; Scharfstein, 1998; Billett \& Mauer, 2003; Ozbas \& Scharfstein, 2009; Hovakimian, 2011), they focus on capital allocation among segments of conglomerates and diversified firms in developed countries.

The second part of this study aims to reveal the role of internal capital markets in shaping the financing choices of affiliated firms, employing the fitted value of investments derived in the first part. Although high-growth firms in emerging markets are expected to use higher levels of trade credit in periods following an investment, owing to the fact that financial markets are less developed, group-affiliated firms are expected to use less trade credit than unaffiliated firms. Internal capital markets of business groups are therefore expected to mitigate the financing constraints of the group affiliates.

Furthermore, less constrained group firms are expected to use higher leverage by substituting trade credit with institutional loans. Relationships in banking may facilitate the access of group-affiliated firms to institutional loans since information asymmetry and hold-up problems can be mitigated in this way. Distressed group-affiliated firms are expected to use higher leverage because a bank has more difficulty inferring the quality of individual members of a group than it does with unaffiliated firms owing to inter-group guarantees that hide the source of payment to the bank (Kim, 2004). Therefore, group firms have a lower likelihood of bankruptcy (Claessens et al., 2003; Kim, 2004), which is expected to lead to a positive relation between financial distress and leverage 
The results of this study indicate that industry Q is positively related to investments supporting Magud and Sosa (2015) who reveal that firms in high Q industries invest more. However, in five of the six emerging markets investigated in this study, group-affiliated firms have significantly lower Q-sensitivity of investments than their unaffiliated counterparts. These findings provide strong support for the premise that group-affiliated firms tend to invest less in high-Q industries, similar to the evidence provided by Ozbas and Scharfstein (2009) in developed markets.

The evidence presented in the first part of this study indicates that investments of group-affiliated firms have lower cash flow sensitivity than unaffiliated firms in all six emerging markets covered, and strongly reveals that affiliates are financially less constrained.

The findings of the present study document a strong positive relationship between capital investments in the prior period and trade credit in the subsequent year. However, in five of the six emerging countries, group affiliated firms that had investments in the prior period tend to use less trade credit than unaffiliated firms with similar investments. The results also reveal a strong positive relationship between financial distress and the use of trade credit, supporting the evidence in the literature (Petersen \& Rajan, 1997; Nilsen, 2002; Molina \& Preve, 2012). While financial distress has a significant positive relationship with trade credit, distressed group firms, in all six countries investigated, use significantly lower trade credit than distressed unaffiliated firms.

Group affiliation is positively related with leverage in five of the six countries covered in this study. As the capital investments of group-affiliated firms increase, they are expected to use significantly higher leverage. However, this finding is significant in only two of the six countries investigated. On the other hand, distressed group affiliates significantly reduce leverage, in five of the six countries, despite the positive relationship between distress and leverage. Thus, results strongly reveal that the internal capital markets of business groups significantly mitigate the financing constraints of affiliated firms and tend to reduce their reliance on external financing.

A highly significant negative relationship exists between trade credit and debt in each of the six emerging markets, but the results do not provide strong support for the premise that firms substitute debt for trade credit as they become less constrained.

This study contributes to the existing literature in two ways. First, it presents evidence on the effects business groups have on capital investments and reveals that internal capital markets affect corporate investments, in all six emerging countries. The prevalence and diversity of business groups in emerging markets and their effects on capital allocation in these countries make it a notable factor that affects the relationship between investment cash flow sensitivity (ICFS) and capital investments of corporations. The results indicate that group affiliation reduces firms' financing constraints. Second, the paper reveals that business group affiliation affects the financing choices of the group members. It reveals the impact of internal capital markets on firms' financing choices by incorporating the joint effects of firms' capital investments and financial distress levels with group affiliation. The effects of investments and financial distress on the use of trade credit and leverage by group-affiliated firms are investigated in an emerging market setting where market imperfections and financing constraints are more pronounced. The results indicate lower use of external financing by distressed group-affiliated firms that have access to the internal capital markets of their business groups.

\section{Theoretical Background}

Determinants of corporate investment in emerging markets relate to a stream of research on financing constraints. Most of these constraints, resulting from capital market imperfections, have drawn attention to the importance of availability of internal financing for firms' investments. The research on capital investment determinants is generally based on Tobin's Q investment models, and mostly use investment sensitivity of cash flows (ICFS) as an indicator of financial constraints (Fazzari et al., 2000; Fisman \& Love, 2003; Carpenter \& Guaraglia, 2008; Ozbas \& Scharfstein, 2009; Attig \& Cleary, 2014; Magud \& Sosa, 2015). Numerous studies find that more financially constrained firms display higher ICFS than less constrained firms (Fazarri et al., 1988; Almeida \& Campello, 2007; Beatty et al., 2010). Investment cash flow sensitivity has been widely used as a measure of financial constraint despite the criticisms expressed in the finance literature by Kaplan and Zingales (1997), Gomes (2001), Abel and Eberly (2011) and Cleary (1999) and different measures of financial constraints developed such as KZ index (Kaplan \& Zingales, 1997), WWindex (Whited \& Wu, 2006) and SA index (Hadlock \& Pierce, 2010). Several studies have attempted to resolve the contradictory results by employing other variables that affect the relation between ICFS and investment outlays including the marginal cost of capital (Cleary, 1999), foreign direct investment flows (Magud \& Sosa, 2015) and management quality practices (Attig \& Cleary, 2014). Other studies that cast doubt on ICFS as a measure of financial constraint demonstrate that these relationships are particular to firms with positive cash flows or 
that they change over time (Allayannis \& Mozumdar, 2004; Agca \& Mozumdar, 2008; Brown \& Petersen, 2009; Chen \& Chen, 2012). The sensitivity of investment to cash flows is particularly strong for smaller firms (Fazzari et al., 1988; Carpenter \& Guariglia, 2008) and for firms in less financially developed economies (Fisman \& Love, 2003).

The evidence shows that single-segment firms are more sensitive to their cash flows than are comparable smallest segments in diversified firms (Shin \& Stulz, 1998; Ozbas \& Sharfstein, 2009) which supports the view that diversification reduces the cash flow sensitivity of the smallest segment and leads firms to invest differently. Evidence indicates that low cash-flow single-segment firms invest less, which is consistent with the view that internal capital market allows divisions of diversified firms to invest while single segment firms cannot. Findings reveal that as cash flows become large, single-segment firms invest more than diversified firms do. So, conglomerates' segments seem to be slower to invest than single-segment firms in high opportunity industries than in low-opportunity industries (Scharfstein \& Stulz, 1998). Similarly, Ozbas and Scharfstein (2009) document the differences between the Q-sensitivity of investment of stand-alone firms and that of unrelated segments. They show that unrelated segments of conglomerates tend to invest less than stand-alone firms in high-Q industries. The investments of stand-alone firms are therefore more responsive to industry $\mathrm{Q}$ than the investments of unrelated segments. Hovakimian (2011) reveals that conglomerates improve the efficiency of their capital market by increasing the allocation of funds to high-Q divisions relative to low-Q divisions. He also indicates that improvement is greater for conglomerates that are more likely to face more binding constraints, which is consistent with theories stressing the benefits of internal capital markets in the presence of capital market imperfections. Previous studies on internal capital markets indicate that frictions in financial markets, that arise primarily from the information asymmetry between a firm and a lender, can make external financing costly,but these financing constraints can be mitigated if a firm is a subsidiary of a conglomerate with access to the internal capital market of the entire organization or has a parent-subsidiary relation following an acquisition (Stiglitz \& Weiss, 1981; Myers \& Majluf, 1984; Greenwald et al., 1984).

Whether or not internal capital markets operate efficiently has been the focus of a number of researchers (Alchian, 1969; Weston, 1970; Gertner et al., 1994; Li \& Li, 1996; Stein, 1997). Some of these indicate that internal capital markets can mitigate the asymmetric information problem and provide better fund allocation within the conglomerate. However, empirical evidence about the efficiency of internal capital markets is mixed. Stein (1997) argues that individual projects initiated by subsidiaries must compete for scarce funds and that headquarters pick the winners. Similar views that focus on the internal competition among projects within business groups are expressed by Williamson (1975) and Donaldson (1984). When information asymmetry and agency problems are pronounced and credit constraints are binding, the efficient allocation of funds across projects becomes more important.

There is extensive body of literature that documents the fact that internal capital markets of diversified firms enable them to find profitable projects that, because of information asymmetries and agency costs, the external capital market would not be able to finance (Williamson, 1975; Gertner et al., 1994; Fluck \& Lynch, 1999; Stein, 1997; Matsusaka \& Nanda, 2002; Hovakimian, 2011; Maksimovic \& Phillips, 2013). Contrary views, however, are explained by models where the internal capital market allocates too much funding to its weakest divisions. There is extensive evidence which concludes that conglomerates subsidize divisions with weak investment opportunities (Shin \& Stulz, 1998; Scharfstein, 1998; Rajan et al., 2000; Campello, 2002; Billett \& Mauer, 2003; Gopalan et al., 2007). Some of these findings are challenged by Chevalier (1999), who argues that there may be biases arising from unobserved differences between conglomerate diversification and stand-alone firms. Some of these studies rest on the premise that the CEO of a conglomerate acts in the interests of the shareholders, while agency problems at the divisional level are directly related to inefficiencies in the internal capital market (Rajan et al., 2000; Wulf, 2009). By contrast, Scharfstein and Stein (2000) use a two-layer model and claim that not only divisional managers but CEOs are agents acting in their own private interests. Holod (2012) finds evidence pointing to capital market inefficiency revealing that bank holding companies $(\mathrm{BHC})$ with a tiered organization structure are less efficient than non-tiered BHCs. He indicates that agency problems are at the root of internal capital market inefficiencies and maintains that divergence of interests between CEO and shareholders is an important source of internal capital misallocation. In the presence of agency problems, management may use the internal capital market to finance a project with negative net present value and subsidize losing divisions. Scharfstein and Stein (2000) show that inefficiencies are more likely to arise when there is a great deal of divergence in the strength of the divisions and when the CEO has low-powered incentives.

Most studies have focused on the effects of conglomeration on capital allocation among segments of conglomerates and diversified firms in developed markets (Scharfstein, 1998; Shin \& Stulz, 1998; Billett \& Mauer, 2003; Ozbas \& 
Scharfstein, 2009; Hovakimian, 2011). In emerging countries, where financial institutions and markets are less developed, internal capital markets of business groups that exist in different forms (Khanna \& Yafeh, 2005) may constitute an economically rational response to the financing constraints faced by corporations. The finance literature includes discussions on the positive effects of business groups on economic growth as well as criticisms focusing on unfavorable effects of pyramidal corporate structures, such as agency and entrenchment problems, poor utilization of resources, distorted capital allocation in the economy and reduction in the rate of innovation (Morck et al., 2005). The prevalence of pyramidal structures is associated with an undersupply of external capital in emerging markets where lack of transparency, depressed savings and FDI flows make liquidity constraints more binding. However, internal capital markets of business groups help to overcome the frictions in capital markets and stimulate investments. Even if the capital allocation within the group is efficient, capital allocation across group boundaries may be distorted. Whether these problems outweigh the positive effects associated with pyramidal control is unclear. Magud and Sosa (2015) investigate determinants of corporate investments in 38 emerging countries over two decades and show that FDI flows to the emerging markets are associated with a reduction in a firm's financing constraints.

Evidence on the likelihood and costs of bankruptcy for diversified subsidiaries of conglomerates indicates that the likelihood of bankruptcy is lower for group-affiliated firms (Claessens et al., 2003), because the business group can serve as an internal capital market that helps firms financially during periods of distress. Similar evidence is provided by Kim (2004) who develops a model of business groups in emerging markets where banks can not accurately distinguish between good (high productivity) firms and bad firms. Because business groups obscure the productivity of individual firms, the optimal policy might be to full bailout so as not to risk eliminating good firms. Hoshi et al. (1990) reveal that bank-related firms recover more quickly from distress. Further evidence shows that diversification reduces the mortality rate of firms and provides evidence indicating that mature firms pursue diversification strategies as a means to exit stagnant business segments for industries that are more highly valued (Borghesi et al., 2007). Authors reveal that age and size of the firm should be taken into account as well as agency costs. However, the incentive to increase the chances of firm survival by diversification can potentially misalign the interests of managers and shareholders.

Financial development is important for economic growth since developed financial markets more effectively allocate capital to firms with high value projects. In emerging markets, where financial intermediaries and markets are less developed; firms tend to rely on internally generated funds. Petersen and Rajan (1997) suggest that implicit borrowing from suppliers may provide an alternative source of financing and trade credit can be a substitute for institutional financing where financial intermediaries are scarce. Petersen and Rajan $(1994,1997)$ find that firms which are less likely to be credit constrained tend to rely less on the use of trade credit. More recent evidence from a study on 44 emerging countries reveals that, for firms in poorly developed financial markets, trade credit may provide an alternative source of funds (Fisman \& Love, 2003). They indicate that industries with relatively higher dependence on trade credit financing exhibit higher rates of growth in countries with weaker financial institutions.

Other research shows that financial market imperfections create dependence on trade credit as a source of funds (Petersen \& Rajan, 1997; Nilsen, 2002; Atanasova, 2007) and there is increased reliance on trade credit by financially constrained firms during periods of tight money and economic downturns. Firms that are smaller, especially those with less market power and with more unique products, tend to use more trade credit when in distress (Molina \& Preve, 2012). They indicate that trade credit ranks lower than other sources of financing in the pecking order of financing choices and that firms in financial distress choose it as a less than optimal solution. Although an important amount of evidence indicates that distressed firms use more trade credit, the reasons they depend on differ. Firms with weak balance sheet positions or with more severe information asymmetry problems are likely to rely on the use of trade credit, despite its unattractiveness. Low levels of liquidity and profitability increase the probability of facing financial constraints. Another stream of literature on trade credit investigates the impact of the internal capital markets created by conglomerates or business groups on trade credit policy. A study by Deloof and Jegers (1999) focuses on effects of intragroup trade on trade credit policy. Deloof and Jegers (1999) provide evidence that the amount of trade credit used is determined by the availability of internal funds and is an important alternative to short-term and long-term debt. The authors provide evidence that holding companies substitute for the poorly developed capital market in Belgium.

Most of the research on the use of trade credit has indicated that trade credit substitutes for financial credit when the latter is unavailable. Empirical results support the hypothesis that trade credit is taken up by firms as a substitute for institutional finance when they are credit-constrained and firms in financial distress use a significantly larger amount of trade credit (Baxter, 1967; Smith, 1987; Petersen \& Rajan, 1997; Atanasova, 2007; Molina \& Preve, 2012). 
Another study reveals that trade credit is a substitute for debt and shows that the use of trade credit rises during periods of tight money (Atanasova, 2007). As information asymmetry-induced financing constraints increase (Myers and Majluf, 1984), firms raise liquid assets. Long et al. (1993), however, find no evidence to support the notion that trade credit acts as a substitute for conventional loans, pointing out to the fact that theoretical studies on trade credit have moved in different but not mutually exclusive directions. Long et al. (1993) argue that trade credit allows a firm to verify its product quality, so its use may be related to a firm's industry, and complexity of items purchased.

Signaling models of trade credit adopt a contrary view and support the idea that the use of trade credit facilitates access to loans. Signaling models of trade credit indicate that informational asymmetries and agency costs can impede the flow of funds to firms that need financing, and that obtaining supplier credit conveys information to bank loan officers regarding firms' creditworthiness (Biais \& Gollier, 1997; Frank \& Maksimovic, 1998; Atanasova, 2012) and facilitates their access to institutional loans (Antov, 2005; Alphonse et al., 2006). A number of studies focus on the controlling advantage that suppliers have over the firms (Burkhart \& Ellingson, 2004; Cunat, 2007). Other studies rest on the suppliers' advantage of information acquisition (Smith, 1987; Biais \& Gollier, 1997; Jain 2001). Yet; others show that the relatively high price of trade credit implies that only financially constrained buyers will use it (Smith, 1987; Brennan et al., 1988; Petersen \& Rajan, 1997; Danielson \& Scott, 2004; Atanasova, 2007). Proponents of transaction theory of trade credit proponents (Schwartz, 1974; Ferris, 1981) indicate that trade credit is a cash management tool which enables firms to match the timing of cash receipts and disbursements.

\section{Methodology}

\subsection{Data and Variables}

The data for this study comes from Bloomberg and covers the period from 2006 to 2012 . The period before 2006 was omitted because the issuance of IFRS financial statements was made mandatory for Turkish companies in 2005. Since the analyses include lagged values for Tobin's Q and capital expenditures, our sample effectively starts at 2007. Khanna and Yafeh (2007) identify 21 countries in which business groups are predominant. Of these countries, the ones which belong to MSCI index are selected Outlier countries, in terms of sample size, are omitted. Of the remaining countries in the sample, those which have similar GDP growth rates and foreign direct investments are included in the analyses based on data from World Bank Economic Indicators (World Bank, 2016).

The sample thus consists of six emerging markets and includes 1924 companies from South Korea, 438 from Brazil, 366 from Indonesia, 333 from South Africa, 498 from Thailand and 347 from Turkey after matching of firms with respect to size and industry has been performed. Private companies and financial firms are excluded from the analysis. Taking into account missing values, the final total sample consists of 18,266 firm-years. The unaffiliated firms are matched with group- affiliated firms with respect to size and industry. For industry matching, 2-digit SIC codes are employed and nine industry groups are used including energy (87 firms), materials (667 firms), industrials (767 firms), consumer discretionary (823 firms), consumer staples (336 firms), health care (245 firms), information technology (845 firms), telecommunication services (43 firms), and utilities ( 93 firms).

While some studies employ segment or division level data in conglomerates (Scharfstein \& Stein, 2000; Billett \& Mauer, 2003; Ozbas \& Scharfstein, 2009), this study rests on firms affiliated with business groups. Group affiliates are defined as firms where more than $50 \%$ of the shares are controlled by a parent company.

For each company in the sample, basic accounting information and stock price along with group membership and industry information are extracted from the Bloomberg database. Table 1 provides descriptive statistics on the variables used in the empirical analyses including capital expenditures divided by sales (capexsa), cash flow divided by sales (cfsa), industry Q (tq), accounts payable divided by total assets (apta), accounts receivable divided by total assets (arta), operating profit divided by total assets (ebitta), total loans divided by total assets (loanta) and exports divided by total sales (exportsa). The percentages of group affiliates (gr) and financially distressed firms (fd) within each country are also provided. 
Table 1. Descriptive Statistics

\begin{tabular}{|c|c|c|c|c|c|c|c|c|c|}
\hline \multirow[b]{2}{*}{ Variable } & \multicolumn{3}{|c|}{ Brazil } & \multicolumn{3}{|c|}{ Indonesia } & \multicolumn{3}{|c|}{ South Korea } \\
\hline & Obs & Mean & Std. Dev. & Obs & Mean & Std. Dev. & Obs & Mean & Std. Dev. \\
\hline CAPEX/SA & 2027 & 0.2750 & 0.0846 & 2302 & 0.1821 & 0.1408 & 11197 & 0.0975 & 0.0799 \\
\hline $\mathrm{CF} / \mathrm{SA}$ & 2027 & 0.2188 & 0.1545 & 2302 & 0.1173 & 0.0409 & 11197 & 0.1201 & 0.0243 \\
\hline TQ & 2277 & 2.0644 & 1.5455 & 2284 & 2.0852 & 2.0073 & 11222 & 1.1428 & 1.0368 \\
\hline AP/TA & 2278 & 0.2111 & 0.1768 & 2331 & 0.1167 & 0.1248 & 11222 & 0.1034 & 0.0355 \\
\hline AR/TA & 2278 & 0.1037 & 0.0455 & 2331 & 0.1289 & 0.1133 & 11222 & 0.1592 & 0.0451 \\
\hline EBIT/TA & 2276 & 0.1472 & 0.0574 & 2331 & 0.0705 & 0.0459 & 11222 & 0.0447 & 0.0106 \\
\hline EXPORT/SA & 2027 & 0.1583 & 0.1245 & 2302 & 0.1448 & 0.0427 & 11197 & 0.1991 & 0.0581 \\
\hline LOANS/TA & 2278 & 0.3066 & 0.2875 & 2331 & 0.5694 & 0.39 & 11222 & 0.3166 & 0.1417 \\
\hline GR & 3066 & 0.4776 & & 2562 & 0.5775 & & 13468 & 0.3563 & \\
\hline \multirow[t]{2}{*}{ FD } & 3066 & 0.4866 & & 2562 & 0.2689 & & 13468 & 0.3572 & \\
\hline & \multicolumn{3}{|c|}{ South Africa } & \multicolumn{3}{|c|}{ Thailand } & \multicolumn{3}{|c|}{ Turkey } \\
\hline Variable & Obs & Mean & Std. Dev. & Obs & Mean & Std. Dev. & Obs & Mean & Std. Dev. \\
\hline CAPEX/SA & 1519 & 0.1371 & 0.125 & 2909 & 0.0882 & 0.0345 & 1822 & 0.0797 & 0.0451 \\
\hline $\mathrm{CF} / \mathrm{SA}$ & 1519 & 0.2487 & 0.8776 & 2909 & 0.1403 & 0.0922 & 1822 & 0.1286 & 0.0691 \\
\hline TQ & 1574 & 2.101 & 1.7516 & 2856 & 1.3068 & 1.0488 & 1767 & 1.365 & 1.1768 \\
\hline AP/TA & 1576 & 0.2115 & 0.3321 & 2856 & 0.1321 & 0.0365 & 1767 & 0.1424 & 0.1593 \\
\hline AR/TA & 1576 & 0.1411 & 0.277 & 2856 & 0.1474 & 0.1171 & 1767 & 0.1546 & 0.1444 \\
\hline EBIT/TA & 1574 & 0.0807 & 0.0298 & 2856 & 0.0544 & 0.018 & 1767 & 0.0431 & 0.011 \\
\hline EXPORT/SA & 1519 & 0.006 & 0.0013 & 2909 & 0.0961 & 0.0227 & 1822 & 0.1653 & 0.2248 \\
\hline LOANS/TA & 1576 & 0.3992 & 0.1868 & 2856 & 0.3303 & 0.2497 & 1767 & 0.3826 & 0.2788 \\
\hline GR & 2331 & 0.4645 & & 3486 & 0.5244 & & 2429 & 0.4981 & \\
\hline FD & 2331 & 0.4448 & & 3486 & 0.3178 & & 2429 & 0.3912 & \\
\hline
\end{tabular}

Cash flow is measured as operating profits plus depreciation. This common measure of cash flow is not adjusted for taxes, working capital investments, and other factors because of unavailability of data. Tobin's Q is calculated as a ratio of the market value of a given company's equity and liabilities to its corresponding book values, assuming that book and market values for liabilities are equal. Industry $\mathrm{Q}$ is defined as the median $\mathrm{Q}$ of unaffiliated firms within the same industry. If the company reported losses for the previous year, the company is considered financially distressed in line with Altman (1983), DeAngelo and DeAngelo (1990) and Molina and Preve (2009).

\subsection{Empirical Design}

\subsubsection{Hypotheses}

The primary aim of this paper is to analyze the differences in the investment behavior of group affiliates and unaffiliated firms. In the presence of market imperfections such as capital constraints, recessions, or financial distress, firms affiliated with a business group are less constrained because they have access to the internal capital market of the entire organization. Consequently, the investments of group affiliates will be less sensitive to the firm's own cash flows than the investments of an unaffiliated firm. The first part of the analysis aims to investigate this premise for six emerging markets testing the following hypotheses:

Hypothesis 1. The capital investments of a group affiliate have lower sensitivity to its cash flow than that of an unaffiliated firm.

Hypothesis 2. Group affiliates tend to invest less than unaffiliated firms in high-Q industries.

The second part of the paper investigates the impact of capital investments on the use of trade credit and institutional loans in subsequent periods. Capital investments tend to increase the need for working capital in subsequent periods. Therefore, it is anticipated that a higher level of capital investments will likely lead to a higher use of trade payables. 
However, the magnitude of this effect may differ between group affiliates and unaffiliated firms since affiliates have access to the internal capital market of the group.

Hypothesis 3. Capital investments have a positive impact on trade payables in subsequent periods. The magnitude of this relationship is less pronounced for group affiliates than for unaffiliated firms.

Thee finance literature shows that financially distressed firms rely more on trade credit even though trade credit ranks lower than other sources of financing in the pecking order of finance (Molina \& Preve, 2012). In other words, distressed firms depend on trade credit although it is a suboptimal solution. Evidence displays that firms that are less credit constrained tend to rely less on the use of trade credit (Petersen \& Rajan, 1994, 1997). Given that firms affiliated with a business group have access to the internal capital market of the group, they are expected to use lower trade credit than unaffiliated firms, even in financial distress. The internal capital market of the group is expected to mitigate the financing constraints of the group member firms.

Hypothesis 4. Unaffiliated firms are more likely to use trade payables when they are financially distressed. The relationship between financial distress and the use of trade payables is less pronounced in group affiliates.

In addition to increasing the need for working capital in subsequent periods, capital investments could also increase the use of leverage. The evidence in the finance literature indicates that, as firms become less distressed, they tend to reduce the use of trade credit and substitute it with leverage (Petersen \& Rajan, 1994, 1997; Atanasova, 2007; Molina \& Preve, 2012). Group-affiliated firms are expected to use more leverage than unaffiliated firms to finance their capital investments, since leverage ranks higher in the pecking order of finance, and banking relationships facilitate access of group firms to institutional loans by reducing information asymmetries and hold-up problems. Furthermore, evidence displays that group firms are less likely to face bankruptcy. (Claessens et al, 2003; Kim, 2004)

Hypothesis 5. Group-affiliated firms that have investment outlays in the prior period are more likely to use leverage than unaffiliated firms.

Hypothesis 6. Distressed affiliates are expected to use leverage less than unaffiliated firms under financial distress.

\subsubsection{Empirical Model}

First, an analysis is conducted to determine whether there are differences in the investment cash flow sensitivity and Q-sensitivity of investments between group affiliates and unaffiliated firms. The following model, developed by Ozbas and Scharfstein (2009) is used:

$$
C A P E X_{\mathrm{i}(\mathrm{j}) \mathrm{t}-1}=\alpha_{0}+\beta_{1} I n d Q_{\mathrm{j}, \mathrm{t}-1}+\beta_{2} C F S_{\mathrm{it}}+\beta_{3} G R_{\mathrm{it}}+\beta_{4} I n d Q_{\mathrm{j}, \mathrm{t}-1} * G R_{\mathrm{it}}+\beta_{5} C F S_{\mathrm{it}} * G R_{\mathrm{it}}+\varepsilon_{\mathrm{it}}
$$

where,

$C A P E X_{\mathrm{i}(\mathrm{j}) \mathrm{t}-1}$ is the sales-normalized capital spending of company $i$ (operating in industry $j$ ) in year $t-1$

Ind $Q_{\mathrm{j}, \mathrm{t}-\mathrm{1}}$ is the median Tobin's $\mathrm{Q}$ of stand-alone firms in industry $j$ in year $t-1$

$C F S_{\text {it }}$ is the sales normalized cash flow of company $i$ at time $t$

$G R_{\mathrm{it}}$ is the binary variable, which takes the value of 1 for group affiliates and 0 for stand-alone firms

$\varepsilon_{\mathrm{it}}$ is the error term.

Given that larger companies may exhibit lower Q-sensitivity of investment or lower investment cash flow sensitivity due to greater technological adjustment costs, group-affiliated firms and unaffiliated firms are matched based on size and industry, following the methodology of Ozbas and Scharfstein (2009). The matching procedure allows the elimination of the effect of firm size on intercept and slope terms by running a differenced specification.

Equation 1 is run separately for each of the six countries in the sample. Although the data is in panel structure, the existence of a time invariant variable (GR) does not allow using a fixed effects model. Moreover, the Hausman (1978) test reveals a violation of the assumptions of the random effects model. As a result, the estimation is conducted using pooled OLS methodology, and robust standard errors are reported.

In the second stage, we aim to reveal whether there are differences between group affiliates and unaffiliated companies in the use of trade credit and loans. Equation (2) is constructed to show the determinants of use of trade credit and equation (3) includes the determinants of leverage.

In addition to well-documented determinants of trade credit such as operating profit, exports, accounts receivable and loans, it is anticipated that capital spending may have an impact on trade payables in subsequent periods and thus a lagged value of capital expenditures is included as an independent variable in the model. Moreover, financial distress is included among the independent variables. The interaction of capital expenditures and financial distress with a group membership dummy is also included in the analyses since the impact of these two variables may differ 
depending on whether the company is affiliated with a business group or not.

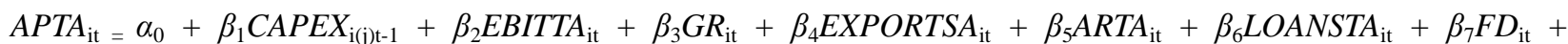
$\beta_{8} C A P E X_{\mathrm{i}(\mathrm{j}) \mathrm{t}-1} * G R_{\mathrm{it}}+\beta_{9} F D_{\mathrm{it}}^{*} G R_{\mathrm{it}}+\varepsilon_{\mathrm{it}}$

where,

$A P T A_{\text {it }}$ denotes accounts payable normalized by total assets for company $i$ at time $t$

$C A P E X_{\mathrm{i}(\mathrm{j}) \mathrm{t}-1}$ is the sales-normalized capital spending of company $i$ (operating in industry $j$ ) in year $t-1$

$E B I T T A_{\text {it }}$ is the EBIT divided by total assets for company $i$ at time $t$

$G R_{\mathrm{it}}$ is the binary variable, which takes the value of 1 for group affiliates and 0 for stand-alone firms

EXPORTSA $A_{\text {it }}$ is the ratio export sales to sales for company $i$ at time $t$

$A R T A_{\text {it }}$ is the total assets normalized accounts receivables of company $i$ at time $t$

$L O A N S T A_{\mathrm{it}}$ is the interest bearing loans other than trade credits divided by total assets for company $i$ at time $t$

$F D_{\text {it }}$ is the dummy variable, which indicates whether a company is financially distressed.

$\varepsilon_{\mathrm{it}}$ is the error term.

Finally, regression equation (3) attempts to determine whether there are systematic differences between group affiliates and stand-alone companies with respect to the use of loans:

LOANSTA $_{\mathrm{it}}=\alpha_{0}+\beta_{1}$ CAPEX $_{\mathrm{i}(\mathrm{j}) \mathrm{t}-1}+\beta_{2}$ EBITTA $_{\mathrm{it}}+\beta_{3} G R_{\mathrm{it}}+\beta_{4}$ EXPORTSA $_{\mathrm{it}}+\beta_{5}$ ARTA $_{\mathrm{it}}+\beta_{6} A P T A_{\mathrm{it}}+\beta_{7} F D_{\mathrm{it}}+$ $\beta_{8} C A P E X_{\mathrm{ij}(\mathrm{)})-1} * G R_{\mathrm{it}}+\beta_{9} F D_{\mathrm{it}} * G R_{\mathrm{it}}+\varepsilon_{\mathrm{it}}$

where the variables are the same as above.

When estimating equations (2) and (3), one issue that arises is the potential endogeneity of the CAPEX variable. Some omitted factors may affect both investment decisions and use of trade credit or loans, causing the error terms in equation (1) to be correlated with the error terms in equation (2) or (3). To investigate whether this is the case, the Durbin-Wu-Hausman test of endogeneity is conducted, which concludes that endogeneity is indeed a problem for both equation (2) $(F=15.21, p<.01)$ and equation (3) $(F=14.41, p<.01)$, leading to inconsistent OLS estimates. To address this problem, equations (2) and (3) are estimated using two-stage least squares regressions where the predicted value of CAPEX from equation (1) is used as an independent variable in equation (2) and equation (3). All analyses were performed using Stata 12 software.

\section{Results}

Results of univariate analyses, displayed in Table 2, show that capital expenditures are higher in group-affiliated firms than unaffiliated firms, in the six emerging markets covered, despite low significance levels. However, the group affiliates have significantly higher cash flows than their unaffiliated counterparts in all markets. The operating profitability of affiliates is significantly higher in four of the six markets; differences are insignificant in the other two markets. When financing policies are analyzed, group-affiliated firms use significantly less trade credit than unaffiliated firms in all six countries. In four countries, there are no significant differences between groups in the use of leverage. The findings reveal that only in Turkey and Brazil, do group firms use significantly higher leverage. This relation is weaker than the findings related to trade credit. 
Table 2. Univariate t-Test Results

\begin{tabular}{|c|c|c|c|c|c|c|}
\hline & Brazil & Indonesia & South Korea & South Africa & Thailand & Turkey \\
\hline \multicolumn{7}{|l|}{ EBITTA } \\
\hline Non group & 0.0670 & 0.0641 & 0.0328 & 0.0303 & 0.0472 & 0.0030 \\
\hline Group & 0.1579 & 0.0736 & 0.0612 & 0.1085 & 0.0577 & 0.0603 \\
\hline $\mathrm{t}$ & $2.7618 * * *$ & 1.3458 & $14.069 * * *$ & $5.0123 * * *$ & 1.4378 & $10.4261 * * *$ \\
\hline \multicolumn{7}{|l|}{ CF/TA } \\
\hline Non group & 0.194019 & 0.1374 & 0.2677 & 0.24859 & 0.2458 & 0.2021 \\
\hline Group & 0.235096 & 0.2318 & 0.3034 & 0.2809622 & 0.2754 & 0.2598 \\
\hline $\mathrm{t}$ & $2.7098 * * *$ & $4.2345 * * *$ & $3.9500 * * *$ & $4.1238 * * *$ & $4.3156 * * *$ & $5.9611 * * *$ \\
\hline \multicolumn{7}{|l|}{ CAPEXSA } \\
\hline Non group & 0.1038 & 0.1221 & 0.0828 & 0.0505 & 0.0661 & 0.0562 \\
\hline Group & 0.2957 & 0.2251 & 0.1178 & 0.1408 & 0.0983 & 0.0904 \\
\hline $\mathrm{t}$ & $2.3324 * *$ & $1.9957^{*}$ & $1.8377^{*}$ & $2.1539 * *$ & $2.1945^{* *}$ & $2.5032 * *$ \\
\hline \multicolumn{7}{|l|}{ APTA } \\
\hline Non group & 1.7237 & 0.1774 & 0.1067 & 0.2170 & 0.2173 & 0.2420 \\
\hline Group & 0.0968 & 0.0884 & 0.0099 & 0.1209 & 0.1386 & 0.1426 \\
\hline $\mathrm{t}$ & $2.3850 * *$ & $1.9758 *$ & $2.5849 * * *$ & $3.2899 * * *$ & $2.3456 * *$ & $1.9991 *$ \\
\hline \multicolumn{7}{|l|}{ LOAN/TA } \\
\hline Non group & 0.1001 & 0.5379 & 0.3103 & 0.2498 & 0.3532 & 0.3362 \\
\hline Group & 0.1967 & 0.4908 & 0.3253 & 0.2895 & 0.3203 & 0.4905 \\
\hline $\mathrm{t}$ & $1.9748 *$ & 1.2345 & 0.9987 & 1.2367 & 1.4673 & $2.1348 * *$ \\
\hline
\end{tabular}

$* * * * *$, and $*$ denote significance at $1 \%, 5 \%$, and $10 \%$ respectively.

Table 3 shows the estimation results for equation (1). The results document that, consistent with finance literature, the firm's own cash flows have a positive impact on capital investments in subsequent periods. The coefficient of the cash flow/sales variable ranges from 0.12 (Indonesia) to 0.61 (Thailand). In addition, the negative interaction terms indicate that in five of the six emerging markets analyzed (Thailand is the exception), investments of group affiliates have lower cash flow sensitivity than unaffiliated firms, supporting the findings of Shin and Stulz (1998). The net effect for group affiliates ranges from 0.038 (Indonesia) to0.393 (South Africa), thus supporting the evidence that internal capital markets mitigate the effects of frictions in financial markets. Firms with high cash flows tend to invest more. However, the effect is less pronounced for group affiliates than for unaffiliated firms, indicating that hypothesis 1 is accepted. The results also indicate that investment opportunities, as given by the average industry Tobin's Q, positively affect capital expenditures. Moreover, the negative interaction term indicates that group affiliates in high-Q industries tend to invest less than the unaffiliated firms do, supporting the evidence provided by Ozbas and Scharfstein (2009). The results are significant in all markets in the sample, supporting hypothesis 2. 
Table 3. Determinants of Capital Investments: Equation 1 Regression Results

\begin{tabular}{|c|c|c|c|c|c|c|c|c|c|}
\hline & \multicolumn{3}{|c|}{ Brazil } & \multicolumn{3}{|c|}{ Indonesia } & \multicolumn{3}{|c|}{ South Korea } \\
\hline & Coef. & Std. Err. & $\mathrm{t}$ & Coef. & Std. Err. & $\mathrm{t}$ & Coef. & Std. Err. & $\mathrm{t}$ \\
\hline Lagged industry Q & 0.5517 & 0.1293 & $4.2667 * * *$ & 0.1355 & 0.0280 & $4.8356^{* * *}$ & 0.2021 & 0.0307 & $6.5897 * * *$ \\
\hline Cash Flow/Sales & 0.2900 & 0.1330 & $2.1805^{* *}$ & 0.3680 & 0.0702 & $5.2422 * * *$ & 0.1220 & 0.0272 & $4.4853 * * *$ \\
\hline Lagged industry $\mathrm{Q}^{*} \mathrm{GR}$ & -0.3950 & 0.1294 & $-3.0541 * * *$ & -0.1424 & 0.0466 & $-3.0578 * * *$ & -0.2193 & 0.0321 & $-6.8424 * * *$ \\
\hline Cash Flow/Sales*GR & -0.1130 & 0.0584 & $-1.9349 *$ & -0.2940 & 0.0757 & $-3.8838 * * *$ & -0.0817 & 0.0273 & $-2.9927 * * *$ \\
\hline GR & 0.1954 & 0.0664 & $2.9438 * * *$ & 0.2058 & 0.0760 & $2.7092 * *$ & 0.2820 & 0.0960 & $2.9372 * * *$ \\
\hline Constant & -0.0473 & 0.0492 & -0.9600 & -0.2332 & 0.0630 & $-3.7028^{* * *}$ & -0.0605 & 0.0127 & $-4.7612 * * *$ \\
\hline $\mathrm{F}$ & 399.73 & & & 5.2 & & & 419.89 & & \\
\hline Prob. & $<.001$ & & & 0.008 & & & $<.001$ & & \\
\hline Adj R2 & 0.3521 & & & 0.1330 & & & 0.1816 & & \\
\hline \multirow[t]{3}{*}{$\mathrm{N}$} & 1694 & & & 1933 & & & 9437 & & \\
\hline & \multicolumn{3}{|c|}{ South Africa } & \multicolumn{3}{|c|}{ Thailand } & \multicolumn{3}{|c|}{ Turkey } \\
\hline & Coef. & Std. Err. & $\mathrm{t}$ & Coef. & Std. Err. & $\mathrm{t}$ & Coef. & Std. Err. & $\mathrm{t}$ \\
\hline Lagged industry Q & 0.3436 & 0.0595 & $5.7722 * * *$ & 0.0280 & 0.0100 & $2.7960 * * *$ & 0.3457 & 0.0576 & $5.9973 * * *$ \\
\hline Cash Flow/Sales & 0.3930 & 0.1340 & $2.9328^{* * *}$ & 0.6100 & 0.2510 & $2.4303^{* *}$ & 0.2688 & 0.1095 & $2.4548 * *$ \\
\hline Lagged industry $\mathrm{Q}^{*} \mathrm{GR}$ & -0.3191 & 0.0610 & $-5.2278 * * *$ & -0.0085 & 0.0007 & $-11.4514 * * *$ & -0.3052 & 0.0580 & $-5.2631 * * *$ \\
\hline Cash Flow/Sales*GR & -0.0001 & 0.0000 & $-4.7325 * * *$ & 0.0000 & 0.0000 & -0.1591 & -0.2547 & 0.1099 & $-2.3176 * *$ \\
\hline GR & 0.1329 & 0.0365 & $3.6402 * * *$ & 0.6823 & 0.0671 & $10.1723^{* * *}$ & 0.0339 & 0.0076 & $4.4524 * * *$ \\
\hline Constant & -0.0735 & 0.0293 & $-2.5128 * *$ & -0.0788 & 0.0469 & $-1.6812 *$ & -0.0330 & 0.0065 & $-5.0788 * * *$ \\
\hline $\mathrm{F}$ & 7.43 & & & 29.68 & & & 17.38 & & \\
\hline Prob. & 0.006 & & & 0.003 & & & 0.005 & & \\
\hline Adj R2 & 0.1248 & & & 0.2555 & & & 0.1520 & & \\
\hline $\mathrm{N}$ & 1265 & & & 2442 & & & 1495 & & \\
\hline
\end{tabular}

$* * *, * *$, and $*$ denote significance at $1 \%, 5 \%$, and $10 \%$ respectively.

Estimation results for the use of trade credit, in equation (2) are presented in Table 4. The results indicate a strong positive relationship, in five emerging markets, between investment expenditures and the use of trade credit in subsequent years. The analyses also display that, in five of the six markets, this effect is less pronounced for group affiliates, as demonstrated by the negative interaction terms. This finding supports hypothesis 3 and provides evidence that group affiliates that had capital expenditures in previous periods rely less on trade credit financing than unaffiliated firms that had similar capital spending in previous periods. In other words, the lagged effect of capital expenditures on trade credit policy seems to differ for group firms and unaffiliated firms. The results also indicate that financial distress leads to higher use of trade credit as shown by the positive and statistically significant coefficient of the financial distress variable in equation (2). The coefficient ranges from 0.0067 for South Africa to 0.3937 in Thailand, a finding that is consistent with studies showing that firms facing financing constraints rely heavily on the use of trade credit, especially during periods of tight money and economic downturns. Similarly, distressed firms use more trade credit because they lack access to financial markets (Baxter, 1967; Smith, 1987; Rajan et al., 1997; Petersen \& Rajan, 1997; Nilsen, 2002; Frank \& Maksimovic, 1998; Molina \& Preve, 2012). Findings of this study are consistent with these studies. The negative interaction terms, however, show that group affiliates depend significantly less on trade credit in periods of financial distress than their unaffiliated counterparts. The results are significant in five of the six emerging markets and the coefficients of the interaction terms range from -0.0113 (South Africa) to -0.2025 (Indonesia). These findings reveal that group affiliates suffer less in periods of financial distress because they have access to the internal capital market of the entire organization. This finding supports the evidence from Petersen and Rajan $(1994,1997)$ and hypothesis 4 is accepted. It might be the case that internal capital markets mitigate the financial constraints faced by distressed group affiliates (Stiglitz \& Weiss, 1981; 
Greenwald et al., 1984; Claessens et al., 2003).

Table 4. Determinants of the Use of Trade Credit: Equation 2 Regression Results

\begin{tabular}{|c|c|c|c|c|c|c|c|c|c|}
\hline & \multicolumn{3}{|c|}{ Brazil } & \multicolumn{3}{|c|}{ Indonesia } & \multicolumn{3}{|c|}{ South Korea } \\
\hline & Coef. & Std. Err. & $\mathrm{z}$ & Coef. & Std. Err. & $\mathrm{z}$ & Coef. & Std. Err. & $\mathrm{z}$ \\
\hline CAPEXt-1 & 0.0527 & 0.0175 & $3.0138 * * *$ & 0.1135 & 0.0434 & $2.6192 * *$ & 0.4054 & 0.1088 & $3.7249 * * *$ \\
\hline EBITTA & 0.1031 & 0.0140 & $7.3860 * * *$ & 0.7234 & 0.0624 & $11.5893 * * *$ & 0.0573 & 0.0842 & 0.6800 \\
\hline EXPORTSA & 0.0132 & 0.0556 & 0.2370 & -0.1110 & 0.0337 & $-3.2979 * * *$ & -0.0041 & 0.0069 & -0.5925 \\
\hline GR & -0.0888 & 0.0454 & $-1.9576^{*}$ & -0.2239 & 0.0941 & $-2.3791 * *$ & -0.0103 & 0.0012 & $-8.9620 * * *$ \\
\hline AR/TA & 0.5023 & 0.0920 & $5.4596 * * *$ & 0.3530 & 0.0651 & $5.4223 * * *$ & 0.4243 & 0.0537 & $7.9067 * * *$ \\
\hline LOANS & -0.0094 & 0.0052 & $-1.7839 *$ & -0.3147 & 0.0212 & $-14.8135^{* * *}$ & -0.0825 & 0.0301 & $-2.7406 * * *$ \\
\hline CAPEXt- $1 *$ GR & -0.0505 & 0.0225 & $-2.2466^{* *}$ & -0.1078 & 0.0433 & $-2.4880 * *$ & -0.2943 & 0.1104 & $-2.6656 * *$ \\
\hline FD & 0.0827 & 0.0313 & $2.6365^{* *}$ & 0.1543 & 0.0396 & $3.8981 * * *$ & 0.0445 & 0.0246 & $1.8114 *$ \\
\hline $\mathrm{FD} * \mathrm{GR}$ & -0.1726 & 0.0641 & $-2.6949 * *$ & -0.2025 & 0.0455 & $-4.4528 * * *$ & -0.0821 & 0.0374 & $-2.1935^{* *}$ \\
\hline Constant & 0.0575 & 0.0515 & 1.1169 & -0.2176 & 0.0934 & $-2.3285 * *$ & 0.0427 & 0.1150 & 0.3713 \\
\hline Wald chi2 & 63.59 & & & 749.96 & & & 223.67 & & \\
\hline Prob. & 0.003 & & & $<.001$ & & & $<.001$ & & \\
\hline $\mathrm{R} 2$ & 0.267 & & & 0.1803 & & & 0.173 & & \\
\hline \multirow[t]{3}{*}{$\mathrm{N}$} & 1692 & & & 1880 & & & 9431 & & \\
\hline & \multicolumn{3}{|c|}{ South Africa } & \multicolumn{3}{|c|}{ Thailand } & \multicolumn{3}{|c|}{ Turkey } \\
\hline & Coef. & Std. Err. & $\mathrm{z}$ & Coef. & Std. Err. & $\mathrm{z}$ & Coef. & Std. Err. & $\mathrm{z}$ \\
\hline CAPEXt-1 & 0.0420 & 0.0272 & 1.5446 & 0.0952 & 0.0317 & $3.0065 * * *$ & 0.3405 & 0.1193 & $2.8549 * * *$ \\
\hline EBITTA & 0.0312 & 0.0157 & $1.9876 *$ & -1.7546 & 0.3421 & $-5.1283 * * *$ & 0.2302 & 0.0562 & $4.0954 * * *$ \\
\hline EXPORTSA & 0.0072 & 0.0025 & $2.8765^{* * *}$ & -0.0066 & 0.0239 & -0.2777 & -0.0130 & 0.0231 & -0.5604 \\
\hline GR & -0.0506 & 0.0254 & $-1.9890^{*}$ & -0.3464 & 0.1590 & $-2.1782 * *$ & -0.3817 & 0.1337 & $-2.8542 * * *$ \\
\hline $\mathrm{AR} / \mathrm{TA}$ & 0.4843 & 0.0093 & $52.1659 * * *$ & 0.3287 & 0.0465 & $7.0721 * * *$ & 0.4262 & 0.0351 & $12.1364 * * *$ \\
\hline LOANS & -0.0669 & 0.0087 & $-7.7147 * * *$ & -0.0787 & 0.0325 & $-2.4213 * *$ & -0.2122 & 0.0469 & $-4.5220 * * *$ \\
\hline CAPEXt- 1 *GR & -0.0609 & 0.0270 & $-2.2578 * *$ & -0.0080 & 0.1301 & -0.0615 & -0.3355 & 0.1092 & $-3.0710 * * *$ \\
\hline FD & 0.0067 & 0.0037 & $1.7875 *$ & 0.3937 & 0.0299 & $13.1642 * * *$ & 0.0326 & 0.0149 & $2.1887 * *$ \\
\hline $\mathrm{FD} * \mathrm{GR}$ & -0.0113 & 0.0058 & $-1.9494 *$ & -0.1657 & 0.0347 & $-4.7725 * * *$ & -0.1608 & 0.0325 & $-4.9441 * * *$ \\
\hline Constant & -0.0827 & 0.0379 & $-2.1800 * *$ & -0.0796 & 0.1496 & -0.5317 & -0.3983 & 0.2196 & $-1.8141 *$ \\
\hline Wald chi2 & 404.87 & & & 362.32 & & & 363.97 & & \\
\hline Prob. & $<.001$ & & & $<.001$ & & & $<.001$ & & \\
\hline R2 & 0.3033 & & & 0.5908 & & & 0.2340 & & \\
\hline $\mathrm{N}$ & 1233 & & & 2387 & & & 1413 & & \\
\hline
\end{tabular}

$* * *, * *$, and $*$ denote significance at $1 \%, 5 \%$, and $10 \%$ respectively.

Finally, Table 5 contains regression results for the use of institutional loans, as defined in equation (3). The results indicate a positive relationship with prior capital expenditures and the use of loans in subsequent years in all six countries. The significance of this positive relationship is very high in five of the six markets. However, it is only in Turkey and Brazil that the interaction term between the capital expenditures variable and the group membership dummy show a significant positive relationship with use of loans. The results are insignificant in the remaining four countries (Indonesia, South Korea, South Africa and Thailand). Hence, there is very limited support for hypothesis 5.

The results show that financial distress significantly increases reliance on loans in five emerging markets, with coefficients ranging from 0.0655 (Turkey) to 7.1665 (Brazil). The impact of financial distress on loan use is 
significantly less for group affiliates than unaffiliated firms in five of the six markets analyzed, Indonesia is the exception, as revealed by the negative coefficient of the interaction term between group dummy and financial distress dummy. The coefficients of the interaction dummy range from -0.032 (South Korea) to -8.735 (Brazil). Hence, hypothesis 6 is accepted revealing that group affiliates depend significantly less on leverage than unaffiliated firms under financial distress.

Table 5. Determinants of Leverage: Equation 3 Regression Results

\begin{tabular}{|c|c|c|c|c|c|c|c|c|c|}
\hline & \multicolumn{3}{|c|}{ Brazil } & \multicolumn{3}{|c|}{ Indonesia } & \multicolumn{3}{|c|}{ South Korea } \\
\hline & Coef. & Std. Err. & $\mathrm{z}$ & Coef. & Std. Err. & $\mathrm{z}$ & Coef. & Std. Err. & $\mathrm{z}$ \\
\hline CAPEXt-1 & 0.5893 & 0.1147 & $5.1400 * * *$ & 0.0072 & 0.0025 & $2.8765 * * *$ & 0.0145 & 0.0026 & $5.5900 * * *$ \\
\hline EBITTA & -6.1219 & 0.7076 & $-8.6500 * * *$ & -1.1565 & 0.0660 & $-17.5400 * * *$ & -0.2385 & 0.0283 & $-8.4200 * * *$ \\
\hline EXPORTSA & -1.6199 & 4.9257 & -0.3300 & 0.1606 & 0.0349 & $4.6000 * * *$ & 0.0050 & 0.0037 & 1.3400 \\
\hline GR & 0.0473 & 0.0078 & $6.0800 * * *$ & -0.0194 & 0.0268 & -0.7200 & 0.8141 & 0.9624 & 0.8500 \\
\hline AR/TA & -6.5762 & 3.5370 & $-1.8600^{*}$ & 0.1723 & 0.0689 & $2.5000 * *$ & 0.3571 & 0.0206 & $17.3500 * * *$ \\
\hline AP/TA & -1.0001 & 0.0035 & $-282.7300 * * *$ & -0.9768 & 0.0067 & $-144.7500 * * *$ & -0.9741 & 0.0060 & $-161.1000 * * *$ \\
\hline CAPEXt- $1 * \mathrm{GR}$ & 0.4971 & 0.2052 & $2.4200 * *$ & 0.0012 & 0.0077 & 0.1600 & 0.0132 & 0.0556 & 0.2300 \\
\hline FD & 7.1665 & 1.2824 & $5.5900 * * *$ & 0.0866 & 0.0440 & $1.9700 * *$ & 0.0721 & 0.0075 & $9.6000 * * *$ \\
\hline $\mathrm{FD} * \mathrm{GR}$ & -8.7346 & 1.7369 & $-5.0300 * * *$ & -0.0007 & 0.0509 & -0.0100 & -0.0319 & 0.0119 & $-2.6800 * * *$ \\
\hline Constant & 1.1534 & 0.8281 & 1.3900 & 0.5896 & 0.0266 & $22.1400 * * *$ & 0.3195 & 0.0062 & $51.3600 * * *$ \\
\hline Wald chi2 & 8.916 & & & 234.7 & & & 298.7 & & \\
\hline $\mathrm{R} 2$ & 0.298 & & & 0.173 & & & 0.182 & & \\
\hline Prob. & 0.009 & & & $<.001$ & & & $<.001$ & & \\
\hline \multirow[t]{3}{*}{$\mathrm{N}$} & 1712 & & & 1913 & & & 9443 & & \\
\hline & \multicolumn{3}{|c|}{ South Africa } & \multicolumn{3}{|c|}{ Thailand } & \multicolumn{3}{|c|}{ Turkey } \\
\hline & Coef. & Std. Err. & z & Coef. & Std. Err. & z & Coef. & Std. Err. & $\mathrm{z}$ \\
\hline CAPEXt-1 & 0.0882 & 0.0478 & $1.8500 *$ & 0.0561 & 0.0103 & $5.4400 * * *$ & 0.2315 & 0.0254 & $9.1000 * * *$ \\
\hline EBITTA & -4.4513 & 0.0698 & $-63.7800 * * *$ & -0.1013 & 0.0587 & $-1.7300 *$ & -0.5624 & 0.1184 & $-4.7500 * * *$ \\
\hline EXPORTSA & 0.6533 & 0.2283 & $2.8600 * * *$ & -0.0011 & 0.0274 & -0.0400 & 0.0066 & 0.0470 & 0.1400 \\
\hline GR & 0.0216 & 0.0191 & 1.1300 & 0.0559 & 0.0242 & $2.3100 * *$ & 0.1666 & 0.0445 & $3.7500 * * *$ \\
\hline AR/TA & 0.3240 & 0.1201 & $2.7000 * * *$ & 0.2339 & 0.0568 & $4.1200 * * *$ & 0.2252 & 0.0708 & $3.1800 * * *$ \\
\hline AP/TA & -0.9985 & 0.0045 & $-221.7500 * * *$ & -0.8402 & 0.0255 & $-32.8900 * * *$ & -0.2571 & 0.0805 & $-3.1900 * * *$ \\
\hline CAPEXt- $1 *$ GR & -0.0060 & 0.0196 & -0.3100 & -0.0179 & 0.0151 & -1.1800 & 0.1531 & 0.0418 & $3.6600 * * *$ \\
\hline FD & 0.9412 & 0.0466 & $20.2100 * * *$ & 0.2480 & 0.0294 & $8.4400 * * *$ & -0.0655 & 0.0489 & -1.3400 \\
\hline $\mathrm{FD} * \mathrm{GR}$ & -0.6469 & 0.0612 & $-10.5600 * * *$ & -0.1086 & 0.0336 & $-3.2300 * * *$ & -0.1776 & 0.0276 & $-6.4400 * * *$ \\
\hline Constant & 0.0414 & 0.0861 & 0.4800 & 0.2707 & 0.0222 & $12.2000 * * *$ & 0.1025 & 0.0436 & $2.3500 * *$ \\
\hline Wald chi2 & 593.9 & & & 299.2 & & & 26.41 & & \\
\hline Prob. & $<.001$ & & & $<.001$ & & & 0.002 & & \\
\hline $\mathrm{R} 2$ & 0.2061 & & & 0.3242 & & & 0.2740 & & \\
\hline $\mathrm{N}$ & 1242 & & & 2387 & & & 1419 & & \\
\hline
\end{tabular}

$* * *, * *$, and $*$ denote significance at $1 \%, 5 \%$, and $10 \%$ respectively.

There is significant negative relationship between debt and trade credit in all regression analyses. A strong negative relation between trade credit and leverage in all six countries indicates that these financing sources are substitutes. As firms become less constrained and have increasing access to financial markets, they tend to replace trade credit with leverage, which ranks higher in pecking order of finance. Consequently, trade credit and debt seem to be substitutes, supporting the evidence in the finance literature (Petersen \& Rajan, 1997; Molina \& Preve, 2012). There is a strong 
negative relationship between profitability and leverage in five of the markets studied, which supports pecking order of finance in these countries. That is, firms prefer to use internal financing as profitability rises. Furthermore, a significantly positive relationship between trade receivables and trade payables, in all six markets, supports the transaction theory of trade credit (Schwartz, 1974; Ferris, 1981). In other words, trade credit is a cash management tool and delaying payments enables firms to match the timing of receivables and payables.

The analysis reveals similar results when the 2008-2009 crisis period is excluded from the sample. Alternative measures of financial distress did not significantly affect our findings either. The results are not driven by outliers. Details of robustness check are available from the authors upon request.

The results of this study have practical implications for creditors and investors. The findings show that the internal capital markets of business groups increase the financial flexibility of group-affiliated firms leading them to use less external financing than unaffiliated firms.Consequently,the group firms are less likely to face the risk of bankruptcy which is highly important for lenders and investors in turbulent environments.Furthermore, higher financial flexibility may facilitate corporate access to external funds, and enable borrowing with less restrictions and lower costs.These companies can operate with higher financial slack that may enable them to take advantage of high-NPV investment opportunities which may be value increasing in the long-run.

\section{Conclusion and Discussion}

The evidence provided in this study reveals that internal capital markets have a highly significant impact on the investment and financing behavior of firms that are affiliates of business groups in the emerging markets covered in the analyses.

The findings of this study indicate that a firm's own cash flow has a positive impact on capital expenditures in subsequent periods, and that investments of group affiliates have lower cash flow sensitivity than unaffiliated firms in five of the six emerging markets, supporting Shin and Stulz (1998) and Ozbas and Scharfstein (2009). The results reveal that group-affiliated firms are financially less constrained than unaffiliated firms in five of the emerging markets, and that firms in high-Q industries tend to invest more. However, affiliates in high-Q industries invest less than their unaffiliated counterparts, supporting evidence provided by Ozbas and Scharfstein (2009). The evidence is significant in all emerging markets covered in this study.

The results reveal that affiliates of business groups exhibit financing policies that differ from those of unaffiliated firms. There is a strong positive relationship between capital expenditures and the use of trade credit in subsequent periods in five of the emerging markets examined. However, the lagged effects of capital investments on financing policies show that group firms and unaffiliated corporations have different financing choices. The affiliated firms that have high investments significantly use lower trade credit than unaffiliated firms with similar capital expenditures, in five of the six emerging markets. Since trade credit ranks lower in the pecking order of finance, it is more likely to be used by firms that are financially constrained. The results indicate that members of business groups are less constrained in their financing choices than non-affiliated firms.

There is a positive relationship between capital expenditures and the use of loans in subsequent periods in emerging markets. However, only in two of the emerging markets studied, Turkey and Brazil, do group firms use significantly more leverage than unaffiliated firms. The relationship is insignificant in rest of the countries. This study provides limited support for previous findings indicating that trade credit is displaced by loans as less constrained group firms increase their capital expenditures. The relatively higher cash flows of group-affiliated firms, in all markets, may indicate availability of internal financing for these firms.

The results indicate a strong positive relationship between financial distress and use of trade credit, supporting the previous studies (Baxter, 1967; Smith, 1987; Rajan et al., 1997; Petersen \& Rajan, 1997; Nilsen, 2002; Frank \& Maksimovic, 1998; Molina \& Preve, 2012). However, evidence provided by the present study indicates that distressed group affiliates are less likely to use trade credit than distressed unaffiliated firms, yielding highly significant results in five of the six emerging markets examined. These findings provide further support for the mitigating impact of internal capital markets on financial constraints faced by members of business groups.

Evidence from this study shows that financial distress is positively related with leverage, but that distressed affiliates use less leverage than distressed unaffiliated firms, in five of the six markets. Therefore, distressed affiliates seem to have access to the internal capital market of the group, and are less constrained than distressed unaffiliated firms.

This study contributes to existing literature by displaying strong evidence supporting the premise that internal capital markets serve to mitigate the financial constraints of group-affiliated firms, based on data from six emerging markets. It further shows that financing and investment policies of group-affiliated firms in emerging markets are significantly 
affected by the presence of internal capital markets of business groups. A limitation of the study which can be addressed by future research is the unavailability of division or segment level data for emerging countries.

The effects of internal capital markets of business groups on economic growth may be an area of further research. The evidence on the efficiency of internal capital markets is mixed. Some findings document that it leads to increasing competition for funds among group firms resulting in efficient allocation while others provide evidence for cross-subsidization of weak group firms by the strong ones. Further research can be directed to investigate if the existence of internal capital markets stimulates economic growth through value increasing investments, and whether these effects exist in countries that have relatively stronger governance systems.Group structure may be beneficial in economies with poorly functioning financial markets, and mitigate financial frictions.In most of the emerging markets, high information asymmetry causes external financing to be constrained and expensive.These conditions may make internal capital markets more important in efficient allocation of resources.Future research may be directed to investigate whether the advantages of internal capital markets created by business groups outweigh the disadvantages .

\section{References}

Abel, A. B., \& Eberly, J. C. (2011). How q and cash flow affect investment without frictions: An analytic explanation. The Review of Economic Studies, 78(4), 1179-1200. https://doi.org/10.1093/restud/rdr006

Ağca, Ş., \& Mozumdar, A. (2008). The impact of capital market imperfections on investment-cash flow sensitivity. Journal of Banking \& Finance, 32(2), 207-216. https://doi.org/10.1016/j.jbankfin.2007.02.013

Alchian, A. (1969). Corporate management and property rights. In D. Manne, (Ed.), Economic Policy and the Regulation of Corporate Securities (pp.337-60). Washington, D.C.: American Enterprise Institute.

Allayannis, G., \& Mozumdar, A. (2004). The impact of negative cash flow and influential observations on investment-cash flow sensitivity estimates. Journal of Banking \& Finance, 28(5), 901-930. https://doi.org/10.1016/S0378-4266(03)00114-6

Almeida, H., \& Campello, M. (2007). Financial constraints, asset tangibility, and corporate investment. Review of Financial Studies, 20(5), 1429-1460. https://doi.org/10.1093/rfs/hhm019

Alphonse, P., Ducret, J., \& Séverin, E. (2006). When trade credit facilitates access to bank finance: evidence from US small business data. In MFS (Istanbul) meetings Paper.

Antov, D. (2005). Trade Credit and Institutional Financing: Theory and Evidence. Northwestern University Working Paper.

Atanasova, C. (2007). Access to institutional finance and the use of trade credit. Financial Management, 36(1), 49-67. https://doi.org/10.1111/j.1755-053X.2007.tb00164.x

Atanasova, C. (2012). How do firms choose between intermediary and supplier finance?. Financial Management, 41(1), 207-228. https://doi.org/10.1111/j.1755-053X.2012.01183.x

Attig, N., \& Cleary, S. (2014). Organizational capital and investment cash flow sensitivity: The effect of management quality practices. Financial Management, 43(3), 473-504. https://doi.org/10.1111/fima.12046

Baxter, N. D. (1967). Leverage, risk of ruin and the cost of capital. The Journal of Finance, 22(3), 395-403. https://doi.org/10.2307/2978892

Beatty, A., Scott Liao, W., \& Weber, J. (2010). The effect of private information and monitoring on the role of accounting quality in investment decisions. Contemporary Accounting Research,27(1), 17-47. https://doi.org/10.1111/j.1911-3846.2010.0100 0.x

Biais, B., \& Gollier, C. (1997). Trade credit and credit rationing. Review of Financial Studies, 10(4), 903-937. https://doi.org/10.1093/rfs/10.4.903

Billett, M. T., \& Mauer, D. C. (2003). Cross-subsidies, external financing constraints, and the contribution of the internal capital market to firm value. Review of Financial Studies, 16(4), 1167-1201. https://doi.org/10.1093/rfs/hhg024

Borghesi, R., Houston, J., \& Naranjo, A. (2007). Value, survival, and the evolution of firm organizational structure. Financial Management, 36(3), 5-31. https://doi.org/10.1111/j.1755-053X.2007.tb00078.x

Brennan, M. J., Maksimovics, V., \& Zechner, J. (1988). Vendor financing. The Journal of Finance, 43(5), 1127-1141. https://doi.org/10.2307/2328210 
Brown, J. R., \& Petersen, B. C. (2009). Why has the investment-cash flow sensitivity declined so sharply? Rising R\&D and equity market developments. Journal of Banking \& Finance, 33(5), 971-984. https://doi.org/10.1016/j.jbankfin.2008.10.009

Burkart, M., \& Ellingsen, T. (2004). In-kind finance: A theory of trade credit. The American Economic Review, 94(3), 569-590. https://doi.org/10.1257/0002828041464579

Campello, M. (2002). Internal capital markets in financial conglomerates: Evidence from small bank responses to monetary policy. The Journal of Finance, 57(6), 2773-2805. https://doi.org/10.1111/1540-6261.00512

Carpenter, R. E., \& Guariglia, A. (2008). Cash flow, investment, and investment opportunities: New tests using UK panel data. Journal of Banking \& Finance, 32(9), 1894-1906. https://doi.org/10.1016/j.jbankfin.2007.12.014

Chevalier, J. (1999). Why do firms undertake diversifying mergers? An examination of the investment policies of merging firms. Working paper, University of Chicago.

Claessens, S., Djankov, S., \& Klapper, L. (2003). Resolution of corporate distress in East Asia. Journal of Empirical Finance, 10(1), 199-216. https://doi.org/10.1016/S0927-5398

Cleary, S. (1999). The relationship between firm investment and financial status. The Journal of Finance, 54(2), 673-692. https://doi.org/10.1111/0022-1082.00121

Chen, H. J., \& Chen, S. J. (2012). Investment-cash flow sensitivity cannot be a good measure of financial constraints: Evidence from the time series. Journal of Financial Economics, 103(2), 393-410. https://doi.org/10.1016/j.jfineco.2011.08.009

Cremers, K. M., Huang, R., \& Sautner, Z. (2010). Internal capital markets and corporate politics in a banking group. Review of Financial Studies, 358-401. https://doi.org/10.1093/rfs/hhq121

Cunat, V. (2007). Trade credit: suppliers as debt collectors and insurance providers. Review of Financial Studies, 20(2), 491-527. https://doi.org/10.1093/rfs/hhl015

Danielson, M. G., \& Scott, J. A. (2004). Bank loan availability and trade credit demand. Financial Review, 39(4), 579-600. https://doi.org/10.1111/j.0732-8516.2004.00089

Deloof, M., \& Jegers, M. (1999). Trade credit, corporate groups, and the financing of Belgian firms. Journal of Business Finance \& Accounting, 26(78), 945-966. https://doi.org/10.1111/1468-5957.00281

Donaldson, G. (1984), Managing corporate wealth. New York, NY: Praeger Publishers.

Fazzari, S. M., Hubbard, R. G., Petersen, B. C., Blinder, A. S., \& Poterba, J. M. (1988). Financing constraints and corporate investment. Brookings papers on economic activity, 1988(1), 141-206. https://doi.org/10.2307/2534426

Fazzari, S. M., Hubbard, R. G., \& Petersen, B. C. (2000). Investment-cash flow sensitivities are useful: A comment on Kaplan and Zingales. Quarterly Journal of Economics, 695-705. https://doi.org/10.1162/003355300554773

Ferris, J. S. (1981). A transactions theory of trade credit use. The Quarterly Journal of Economics, 243-270. https://doi.org/10.2307/1882390

Fisman, R., \& Love, I. (2003). Trade credit, financial intermediary development, and industry growth. The Journal of Finance, 58(1), 353-374. https://doi.org/10.1111/1540-6261.00527

Fluck, Z., \& Lynch, A. W. (1999). Why Do Firms Merge and Then Divest? A Theory of Financial Synergy. The Journal of Business, 72(3), 319-346. https://doi.org/10.1086/209617

Frank, M., \& Maksimovic, V. (1998). Trade credit, collateral, and adverse selection. Working paper, University of Maryland. https://doi.org/10.2139/ssrn.87868

Gertner, R. H., Scharfstein, D. S., \& Stein, J. C. (1994). Internal versus external capital markets (No. w4776). National Bureau of Economic Research. https://doi.org/10.2307/2118361

Gilchrist, S., \& Himmelberg, C. P. (1995). Evidence on the role of cash flow for investment. Journal of Monetary Economics, 36(3), 541-572. https://doi.org/10.1016/0304-3932(95)01223-0

Gomes, J. F. (2001). Financing investment. American Economic Review, 91(5), 1263-1285. https://doi.org/10.1257/aer.91.5.1263

Gopalan, R., Nanda, V., \& Seru, A. (2007). Affiliated firms and financial support: Evidence from Indian business groups. Journal of Financial Economics, 86(3), 759-795. https://doi.org/10.1016/j.jfineco.2006.09.008 
Greenwald, B., Stiglitz, J. E., \& Weiss, A. (1984). Informational Imperfections in the Capital Market and Macroeconomic Fluctuations. American Economic Review, 74(2), 194-99.

Hausman, J. A. (1978). Specification tests in econometrics. Econometrica: Journal of the Econometric Society, 1251-1271. https://doi.org/10.2307/1913827

Hadlock, C. J., \& Pierce, J. R. (2010). New evidence on measuring financial constraints: Moving beyond the KZ index. Review of Financial Studies, 23(5), 1909-1940. https://doi.org/10.1093/rfs/hhq009

Holod, D. (2012). Agency and internal capital market inefficiency: Evidence from banking organizations. Financial Management, 4l(1), 35-53. https://doi.org/10.1111/j.1755-053X.2012.01177

Hoshi, T., Kashyap, A., \& Scharfstein, D. (1990). The role of banks in reducing the costs of financial distress in Japan. Journal of Financial Economics, 27(1), 67-88. https://doi.org/10.1016/0304-405X(90)90021-Q

Houston, J. F., \& James, C. (1998). Do bank internal capital markets promote lending?. Journal of Banking \& Finance, 22(6), 899-918. https://doi.org/10.1016/S0378-4266(98)00009-0

Hovakimian, G. (2011). Financial constraints and investment efficiency: Internal capital allocation across the business cycle. Journal of Financial Intermediation, 20(2), 264-283. https://doi.org/10.1016/j.jfi.2010.07.001

Jain, N. (2001). Monitoring costs and trade credit. The Quarterly Review of Economics and Finance, 41(1), 89-110. https://doi.org/10.1016/S1062-9769(00)00063-6

Kaplan, S. N., \& Zingales, L. (1997). Do investment-cash flow sensitivities provide useful measures of financing constraints?. The Quarterly Journal of Economics, 169-215. https://doi.org/10.1162/003355397555163

Khanna, T., \& Yafeh, Y. (2007). Business groups in emerging markets: Paragons or parasites?. Journal of Economic Literature, 45(2), 331-372. https://doi.org/10.1257/jel.45.2.331

Kim, S. J. (2004). Bailout and conglomeration. Journal of Financial Economics, 71(2), 315-347. https://doi.org/10.1016/S0304-405X(03)00191-0

Li, D. D., \& Li, S. (1996). A theory of corporate scope and financial structure. The Journal of Finance, 51(2), 691-709. https://doi.org/10.1111/j.1540-6261.1996.tb02699.x

Long, M. S., Malitz, I. B., \& Ravid, S. A. (1993). Trade credit, quality guarantees, and product marketability. Financial Management, 117-127. https://doi.org/10.2307/3665582

Love, I., \& Zicchino, L. (2006). Financial development and dynamic investment behavior: Evidence from panel VAR. The Quarterly Review of Economics and Finance, 46(2), 190-210. https://doi.org/10.1016/j.qref.2005.11.007

Magud, N. E., \& Sosa, S. (2015). Investment in Emerging Markets: We are Not in Kansas Anymore, Or are We? (No. 15-77). International Monetary Fund. https://doi.org/10.5089/9781475534221.001

Maksimovic, V., \& Phillips, G. M. (2013). Conglomerate Firms, Internal Capital Markets, and the Theory of the Firm. Annual Review of Financial $\quad$ Econonomics, 5(1), 225-244. https://doi.org/10.1146/annurev-financial-110112-120933

Matsusaka, J. G., \& Nanda, V. (2002). Internal capital markets and corporate refocusing. Journal of Financial Intermediation, 11(2), 176-211. https://doi.org/10.1006/jfin.2001.0333

Meyer, M., Milgrom, P., \& Roberts, J. (1992). Organizational prospects, influence costs, and ownership changes. Journal of Economics \& Management Strategy, 1(1), 9-35. https://doi.org/10.1111/j.1430-9134.1992.00009.x

Molina, C. A., \& Preve, L. A. (2012). An empirical analysis of the effect of financial distress on trade credit. Financial Management, 41(1), 187-205. https://doi.org/10.1111/j.1755-053X.2012.01182.x

Morck, R., Wolfenzon, D., \& Yeung, B. (2005). Corporate governance, economic entrenchment, and growth. Journal of Economic Literature, 43(3), 655-720. https://doi.org/10.1257/002205105774431252

Myers, S. C., \& Majluf, N. S. (1984). Corporate financing and investment decisions when firms have information that investors do not have. Journal of Financial Economics, 13(2), 187-221. https://doi.org/10.1016/0304-405X(84)90023-0

Nilsen, J. H. (2002). Trade Credit and the Bank Lending Channel. Journal of Money, Credit, and Banking, 34(1), 226-253. https://doi.org/10.1353/mcb.2002.0032 
Ozbas, O., \& Scharfstein, D. S. (2009). Evidence on the Dark Side of Internal Capital Markets. Review of Financial Studies, 23(2), 581-599. https://doi.org/10.1093/rfs/hhp071

Petersen, M. A., \& Rajan, R. G. (1997). Trade credit: theories and evidence. Review of Financial Studies, 10(3), 661-691. https://doi.org/10.1093/rfs/10.3.661

Petersen, M. A., \& Rajan, R. G. (1994). The benefits of lending relationships: Evidence from small business data. The Journal of Finance, 49(1), 3-37. https://doi.org/10.2307/2329133

Petersen, M. A., \& Rajan, R. G. (1995). The effect of credit market competition on lending relationships. The Quarterly Journal of Economics, 110, 407-443. https://doi.org/10.2307/2118445

Rajan, R., Servaes, H., \& Zingales, L. (1997). Conglomerate Discount and Inefficient Investment. Working Paper. University of Chicago.

Rajan, R., Servaes, H., \& Zingales, L. (2000). The cost of diversity: The diversification discount and inefficient investment. The Journal of Finance, 55(1), 35-80. https://doi.org/10.1111/0022-1082.00200

Scharfstein, D. S. (1998). The dark side of internal capital markets II: Evidence from diversified conglomerates (No. w6352). National Bureau of Economic Research. https://doi.org/10.3386/w6352

Scharfstein, D. S., \& Stein, J. C. (2000). The dark side of internal capital markets: Divisional rent-seeking and inefficient investment. The Journal of Finance, 55(6), 2537-2564. https://doi.org/10.1111/0022-1082.00299

Schwartz, R. A. (1974). An economic model of trade credit. Journal of Financial and Quantitative Analysis, 9(04), 643-657. https://doi.org/10.2307/2329765

Shin, H. H., \& Stulz, R. M. (1998). Are internal capital markets efficient?. Quarterly Journal of Economics, 113, 531-552. https://doi.org/10.1162/003355398555676

Smith, J. K. (1987). Trade credit and informational asymmetry. The Journal of Finance, 42(4), 863-872. https://doi.org/10.1111/j.1540-6261.1987.tb03916.X

Stein, J. C. (1997). Internal capital markets and the competition for corporate resources. The Journal of Finance, 52(1), 111-133. https://doi.org/10.1111/j.1540-6261.1997.tb03810.x

Stiglitz, J. E., \& Weiss, A. (1981). Credit rationing in markets with imperfect information. The American Economic Review, 71(3), 393-410.

Weston, J. F. (2012). The Nature and Significance of Conglomerate Firms. St. John's Law Review, 44(5), 12.

Whited, T. M., \& Wu, G. (2006). Financial constraints risk. Review of Financial Studies, 19(2), 531-559. https://doi.org/10.1093/rfs/hhj012

Williamson O. E. (1975). Markets and hierarchies: Analysis and antitrust implications. New York, NY: Collier Macmillan Publishers.

World Bank (2016). World Bank Economic Indicators Database. Available at: http://data.worldbank.org/topic/economy-and-growth

Wulf, J. (2009). Influence and inefficiency in the internal capital market. Journal of Economic Behavior \& Organization, 72(1), 305-321. https://doi.org/10.1016/j.jebo.2009.07.001 